\title{
Hirschia maritima sp. nov., isolated from seawater
}

Correspondence
Soon Dong Lee
sdlee@cheju.ac.kr

\author{
Hye Soon Kang and Soon Dong Lee
}

Department of Science Education, Cheju National University, Jeju 690-756, Republic of Korea

\begin{abstract}
A Gram-negative, aerobic, orange-coloured bacterium, designated strain GSW-2 ${ }^{\top}$, was isolated from seawater sampled at a beach and its taxonomic status was established by using a polyphasic approach. Vegetative cells produced a prostheca and reproduced by budding. Mature vegetative cells were spherical, oval- or rod-shaped $(0.6-1.1 \times 1.2-1.3 \mu \mathrm{m})$ and both vegetative cells and buds produced one or more flagella. Cells grew well at $30{ }^{\circ} \mathrm{C}$ and at $\mathrm{pH} 8.1-9.1$, and produced a non-diffusible pigment. Phylogenetic analysis based on 16S rRNA gene sequences revealed that strain GSW-2 ${ }^{\top}$ was most closely related to the type strain of Hirschia baltica ( $97.5 \%$ similarity), a member of the family Hyphomonadaceae, class Alphaproteobacteria. Chemotaxonomic characteristics supported the assignment of strain GSW $-2^{\top}$ to the genus Hirschia, including the dominant cellular fatty acids (summed feature 7 and $\mathrm{C}_{16: 0}$ ), isoprenoid quinone (mainly $\mathrm{Q}-10$ ) and DNA G $+\mathrm{C}$ content (44.5 mol\%). Levels of DNA-DNA relatedness between strain GSW-2 ${ }^{\top}$ and Hirschia baltica DSM $5838^{\top}$ were $8.8-13.6 \%$. On the basis of phenotypic features and DNA-DNA hybridization data, strain GSW $-2^{\top}$ is considered to represent a novel species of the genus Hirschia, for which the name Hirschia maritima sp. nov. is proposed. The type strain is GSW-2 ${ }^{\top}$ (=DSM $19733^{\top}=$ JCM $\left.14974^{\top}\right)$.
\end{abstract}

The genus Hirschia was proposed by Schlesner et al. (1990) to accommodate a budding bacterium isolated from the Baltic Sea, Hirschia baltica. This genus, together with members of the genus Hyphomonas (Pongratz, 1957), comprises prosthecate, budding bacteria; the two genera are phylogenetically related to the genera Maricaulis (Abraham et al., 1999), Oceanicaulis (Strömpl et al., 2003) and Robiginitomaculum (Lee et al., 2007) within the family Hyphomonadaceae, class Alphaproteobacteria. During a study of the diversity of marine bacteria, a Hirschia-like bacterium, designated strain GSW $-2^{\mathrm{T}}$, was isolated from seawater collected from the seashore of Jeju, Republic of Korea. Based on data from the present polyphasic study, this strain is considered to represent a novel species of the genus Hirschia.

Strain GSW-2 $2^{\mathrm{T}}$ was isolated from seawater taken from Kimnyeong Beach on the coast of Jeju, Republic of Korea. The seawater sample was directly transferred onto marine agar (MA; Difco). A colony on agar medium, incubated for 8 days at $30{ }^{\circ} \mathrm{C}$, was selected and streaked on MA. After the purity of the culture was verified, the isolate was stored at -20 and $-80{ }^{\circ} \mathrm{C}$ in suspensions supplemented with $60 \%$ $(\mathrm{v} / \mathrm{v})$ natural seawater and $20 \%$ (v/v) glycerol. For phenotypic comparisons, Hirschia baltica DSM $5838^{\mathrm{T}}$ was grown on $\mathrm{MA}$ at $30{ }^{\circ} \mathrm{C}$.

The GenBank/EMBL/DDBJ accession number for the 16S rRNA gene sequence of strain GSW-2 ${ }^{\top}$ is FM202386.
Unless specified otherwise, cultural, physiological and biochemical properties were examined by using MA as the basal medium. The morphology and size of cells and colonies were examined from cultures grown on MA at $30{ }^{\circ} \mathrm{C}$ for 5 days. Cell motility by means of flagella was observed by transmission electron microscopy. The temperature range for growth was tested at 4, 10, 20, 30, 37 and $42{ }^{\circ} \mathrm{C}$. The $\mathrm{pH}$ range for growth was determined on agar media that had been adjusted from $\mathrm{pH} 4.1$ to 12.1 (intervals of $1.0 \mathrm{pH}$ units) prior to sterilization. The requirement for natural seawater or artificial sea salts (Sigma) for growth was tested on yeast extract-malt extract agar, trypticase soy agar (Difco) and nutrient agar (Difco) with or without the addition of $60 \%(\mathrm{v} / \mathrm{v})$ natural seawater or $1 \%(\mathrm{w} / \mathrm{v})$ artificial sea salts, respectively. Tolerance to various $\mathrm{NaCl}$ concentrations for growth was tested in marine broth 2216 (MB; Difco) amended with 0-10\% $\mathrm{NaCl}(\mathrm{w} / \mathrm{v})$ at intervals of $1.0 \% \mathrm{NaCl}$. The $\mathrm{OD}_{600}$ of the cell suspension was adjusted spectrophotometrically to a value of 0.3 . After inoculation in $\mathrm{MB}$, the $\mathrm{OD}_{600}$ of the culture broth was measured at the beginning of the experiment and daily for 5 days by using a spectrophotometer. For detection of bacteriochlorophyll $a$ and carotenoids, pigments of strain GSW $-2^{\mathrm{T}}$ were extracted with acetone/methanol $(1: 1, \mathrm{v} / \mathrm{v})$ and the absorption spectra were determined by using a scanning UV-VIS spectrophotometer (UV mini1240; Shimadzu). Gram staining was carried out by using a GRAM 2 kit (bioMérieux) according to the manufacturer's instructions. Catalase and oxidase activities were tested with $3 \%(\mathrm{v} / \mathrm{v})$ 

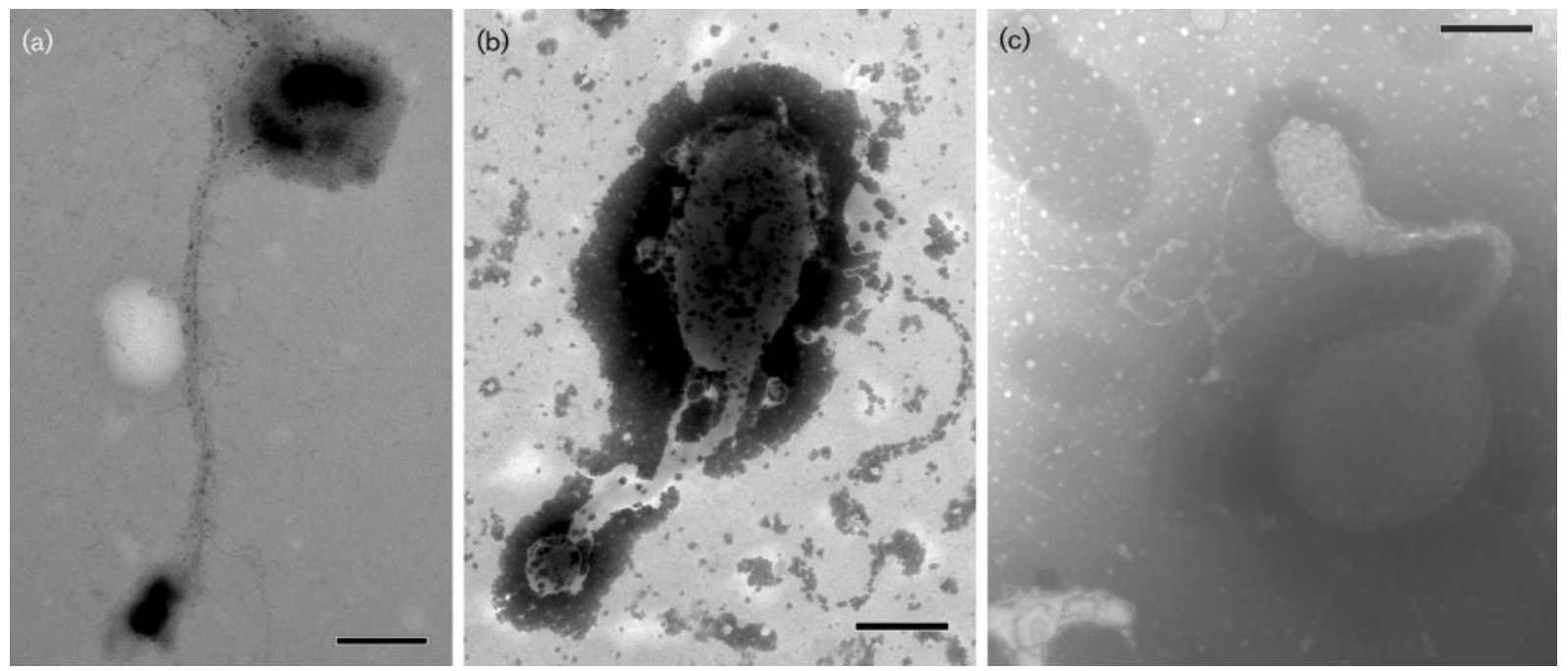

Fig. 1. Transmission electron micrographs of cells of strain GSW-2 ${ }^{\top}$, showing a prosthecate, budding bacterium (a). Note vegetative cell (b) and bud (c) with flagella. Bars, $0.5 \mu \mathrm{m}$.

Table 1. Differential characteristics between strain GSW-2 ${ }^{\top}$ and the type strain of Hirschia baltica

Strains: 1, GSW-2 ${ }^{\mathrm{T}}$; 2, Hirschia baltica DSM $5838^{\mathrm{T}}$ (data from Schlesner et al., 1990 and the present study). +, Positive; -, negative. Both strains grew at $10-30{ }^{\circ} \mathrm{C}$ and at an initial $\mathrm{pH}$ 6.1-10.1 and tolerated up to $1 \% \mathrm{NaCl}$. The strains degraded starch but not elastin, casein, chitin, $\mathrm{CM}-$ cellulose, hypoxanthine, DL-tyrosine or xanthine. Both strains were positive for aesculin degradation but negative for nitrate reduction, indole production, glucose fermentation, arginine dihydrolase and urease (API 20NE). Enzyme activities for alkaline phosphatase, trypsin, acid phosphatase and naphthol-AS-BI-phosphohydrolase were positive in the two strains but esterase (C4), esterase lipase (C8), lipase (C14), valine arylamidase, cystine arylamidase, $\alpha$-chymotrypsin, $\alpha$-galactosidase, $\beta$-glucuronidase, $N$-acetyl- $\beta$-glucosamidase, $\alpha$-mannosidase and $\alpha$-fucosidase were negative (API ZYM). The two strains oxidized Tween 40, Tween 80, L-alanine, L-proline and $\alpha$-D-glucose but did not assimilate 62 other substrates tested (Biolog GN2).

\begin{tabular}{|c|c|c|}
\hline Characteristic & 1 & 2 \\
\hline $4{ }^{\circ} \mathrm{C}$ & - & + \\
\hline $2 \% \mathrm{NaCl}$ & - & + \\
\hline \multicolumn{3}{|l|}{ Hydrolysis of: } \\
\hline DNA & + & - \\
\hline \multicolumn{3}{|l|}{ Enzyme activities: } \\
\hline$\beta$-Galactosidase & + & - \\
\hline$\alpha$-Glucosidase & - & + \\
\hline$\beta$-Glucosidase & - & + \\
\hline Leucine arylamidase & + & - \\
\hline \multicolumn{3}{|l|}{ Oxidation of (Biolog GN2): } \\
\hline Citric acid, L-alaninamide, glycyl L-glutamic acid & - & + \\
\hline DNA G + C content $(\mathrm{mol} \%)$ & 44.5 & 43.7 \\
\hline
\end{tabular}


$\mathrm{H}_{2} \mathrm{O}_{2}$ and $1 \%(\mathrm{w} / \mathrm{v}) \mathrm{N}, N, N^{\prime}, N^{\prime}$-tetramethyl-p-phenylenediamine dihydrochloride solutions, respectively. Growth under anaerobic conditions was tested on MA by using a GasPak EZ anaerobe pouch system (Becton Dickinson). Degradation of casein [skimmed milk $(1 \%, \mathrm{w} / \mathrm{v})$ ], chitin $(0.5 \%, \mathrm{w} / \mathrm{v}), \mathrm{CM}$-cellulose [Sigma; $0.5 \%(\mathrm{w} / \mathrm{v})]$, DNA $(1 \%, \mathrm{w} / \mathrm{v})$, hypoxanthine $(0.4 \%, \mathrm{w} / \mathrm{v})$, starch $(1 \%, \mathrm{w} / \mathrm{v})$, DL-tyrosine $(0.5 \%, \mathrm{w} / \mathrm{v})$ and xanthine $(0.4 \%, \mathrm{w} / \mathrm{v})$ was tested on MA as the basal medium. Respiratory activity in the presence of a carbon substrate was tested by using GN2 microplates of the Microlog system (Biolog) according to the manufacturer's recommendations. Cells were grown on MA for 5 days at $30{ }^{\circ} \mathrm{C}$ and suspended in $2 \%(\mathrm{w} / \mathrm{v})$ sea salts (Sigma) solution. A $150 \mu \mathrm{l}$ sample of the suspension was transferred to each well and the plates were incubated for $48 \mathrm{~h}$ at $30{ }^{\circ} \mathrm{C}$. Other physiological and biochemical properties were tested by using API 20NE and API ZYM strips (bioMérieux) according to the manufacturer's recommendations.

Cells of strain GSW $-2^{\mathrm{T}}$ produced a prostheca and reproduced by budding (Fig. 1a), similar to species of the genera Hirschia (Schlesner et al., 1990) and Hyphomonas (Pongratz, 1957; Moore et al., 1984; Weiner et al., 2000). Vegetative cells produced prostheca $0.06-0.1 \mu \mathrm{m}$ in diameter and a bud formed at the hyphal tip. At maturity, both the vegetative cell and the bud produced one or more flagella (Fig. 1b, c). Vegetative cells were spherical, oval- or rod-shaped and measured about $0.6-1.1 \times 1.2-1.3 \mu \mathrm{m}$. The results of other cultural, physiological and biochemical tests are detailed in Table 1 and in the species description below.

For chemotaxonomic analyses, cells were harvested from liquid culture grown in $\mathrm{MB}$ for 3 days at $30{ }^{\circ} \mathrm{C}$ on a shaking incubator. Isoprenoid quinones were extracted according to the method of Minnikin et al. (1984) and were analysed by HPLC (Kroppenstedt, 1985). Polar lipids were determined by TLC as described by Minnikin et al. (1977). Cellular fatty acids of strain GSW-2 ${ }^{\mathrm{T}}$ and Hirschia baltica DSM $5838^{\mathrm{T}}$ were extracted and identified in accordance with the instructions of the Sherlock Microbial Identification System (MIDI, version 6). Fatty acid methyl esters were prepared and extracted from cells grown on MA for 5 days at $30{ }^{\circ} \mathrm{C}$. The $\mathrm{G}+\mathrm{C}$ content of the DNA was determined by HPLC as described by Mesbah et al. (1989). The DNA G + C content of strain GSW-2 ${ }^{\mathrm{T}}$ was $44.5 \mathrm{~mol} \%$. The major isoprenoid quinone was Q-10. The phospholipid profile comprised only phosphatidylglycerol. These chemotaxonomic characteristics were in agreement with those of the genus Hirschia. The major cellular fatty acids were summed feature $7\left(\mathrm{C}_{18: 1} \omega 9 \mathrm{c} / \omega 12 \mathrm{t}\right)$ $\omega 7 c ; 43.6 \%$ of the total) and $\mathrm{C}_{16: 0}(21.6 \%)$. The fatty acid profile of strain GSW $-2^{\mathrm{T}}$ was similar to that of Hirschia baltica DSM $5838^{\mathrm{T}}$, but differed in having certain unsaturated $\left(\mathrm{C}_{15: 1} \omega 8 c\right.$ and $\left.\mathrm{C}_{17: 1} \omega 6 c\right)$ and hydroxy $\left(\mathrm{C}_{12: 0}\right.$ 3-OH and $\mathrm{C}_{12: 1} 3-\mathrm{OH}$ ) minor components (Table 2).

DNA separation and PCR amplification of the 16S rRNA gene were performed as described by Lee (2007). The PCR
Table 2. Cellular fatty acid compositions of strain GSW-2 ${ }^{\top}$ and Hirschia baltica DSM $5838^{\top}$

Strains: 1, GSW $-2^{\mathrm{T}} ; 2$, Hirschia baltica DSM $5838^{\mathrm{T}}$. Components comprising $<1 \%$ of the total fatty acids in both strains were omitted. - , Not determined or not described.

\begin{tabular}{|lcc|}
\hline Fatty acid & $\mathbf{1}$ & $\mathbf{2}$ \\
\hline Saturated fatty acids & & \\
$\mathrm{C}_{14: 0}$ & 3.1 & 2.7 \\
$\mathrm{C}_{15: 0}$ & 6.0 & 8.1 \\
$\mathrm{C}_{16: 0}$ & 21.6 & 24.5 \\
$\mathrm{C}_{17: 0}$ & 2.1 & 1.5 \\
$\mathrm{C}_{18: 0}$ & 2.0 & 2.5 \\
Unsaturated fatty acids & & \\
$\mathrm{C}_{15: 1} \omega 8 c$ & 1.6 & - \\
$\mathrm{C}_{16: 1} \omega 11 c$ & 2.1 & 2.7 \\
$\mathrm{C}_{17: 1} \omega 8 c$ & 2.0 & 1.1 \\
$\mathrm{C}_{17: 1} \omega 6 c$ & 1.0 & - \\
Branched fatty acids & & \\
anteiso-C $15: 0$ & 1.0 & 1.1 \\
anteiso-C $17: 0$ & 1.0 & 1.4 \\
Hydroxy fatty acids $\mathrm{C}_{12: 1} 3-\mathrm{OH}$ & & \\
$\mathrm{C}_{12: 0} 3-\mathrm{OH}$ & 2.0 & - \\
Summed feature & 1.7 & - \\
4 & & \\
7 & 2.0 & 3.2 \\
& 43.6 & 43.8 \\
\hline
\end{tabular}

${ }^{\star}$ Each summed feature contains a combination of one or more fatty acids that cannot be separated by GLS with the MIDI system. Summed features 4 and 7 consist of $\mathrm{C}_{16: 1} \omega 7 c$ and/or iso- $\mathrm{C}_{15: 0} 2-\mathrm{OH}$, and $\mathrm{C}_{18: 1} \omega 9 c / \omega 12 t / \omega 7 c$, respectively.

product was purified by using the Wizard PCR Preps DNA purification system (Promega) and was subjected to direct sequencing as described by Lee (2007). The CLUSTAL_X software (Thompson et al., 1997) was used for multiple alignments of the $16 \mathrm{~S}$ rRNA gene sequence of strain GSW-2 ${ }^{\mathrm{T}}$ and the corresponding sequences of representatives retrieved from public databases. Phylogenetic analyses were performed by using the NEIGHBOR, DNAML and DNAPARS programs contained within the PHYLIP package (Felsenstein, 1993). A phylogenetic tree was generated by using the neighbour-joining method (Saitou \& Nei, 1987) with evolutionary distances calculated by the model of Jukes \& Cantor (1969). Alteromonas addita R10SW $13^{\mathrm{T}}$ (GenBank accession no. AY682202) was used as the outgroup taxon. Bootstrap analysis (Felsenstein, 1985) to evaluate the tree topology was performed with 1000 replications of the neighbour-joining dataset.

A partial 16S rRNA gene sequence (1336 nt) of strain GSW $-2^{\mathrm{T}}$ was compared with those of members of the family Hyphomonadaceae. The neighbour-joining tree (Fig. 2) revealed that strain GSW-2 ${ }^{\mathrm{T}}$ formed a coherent clade with the type strain of Hirschia baltica (16S rRNA 


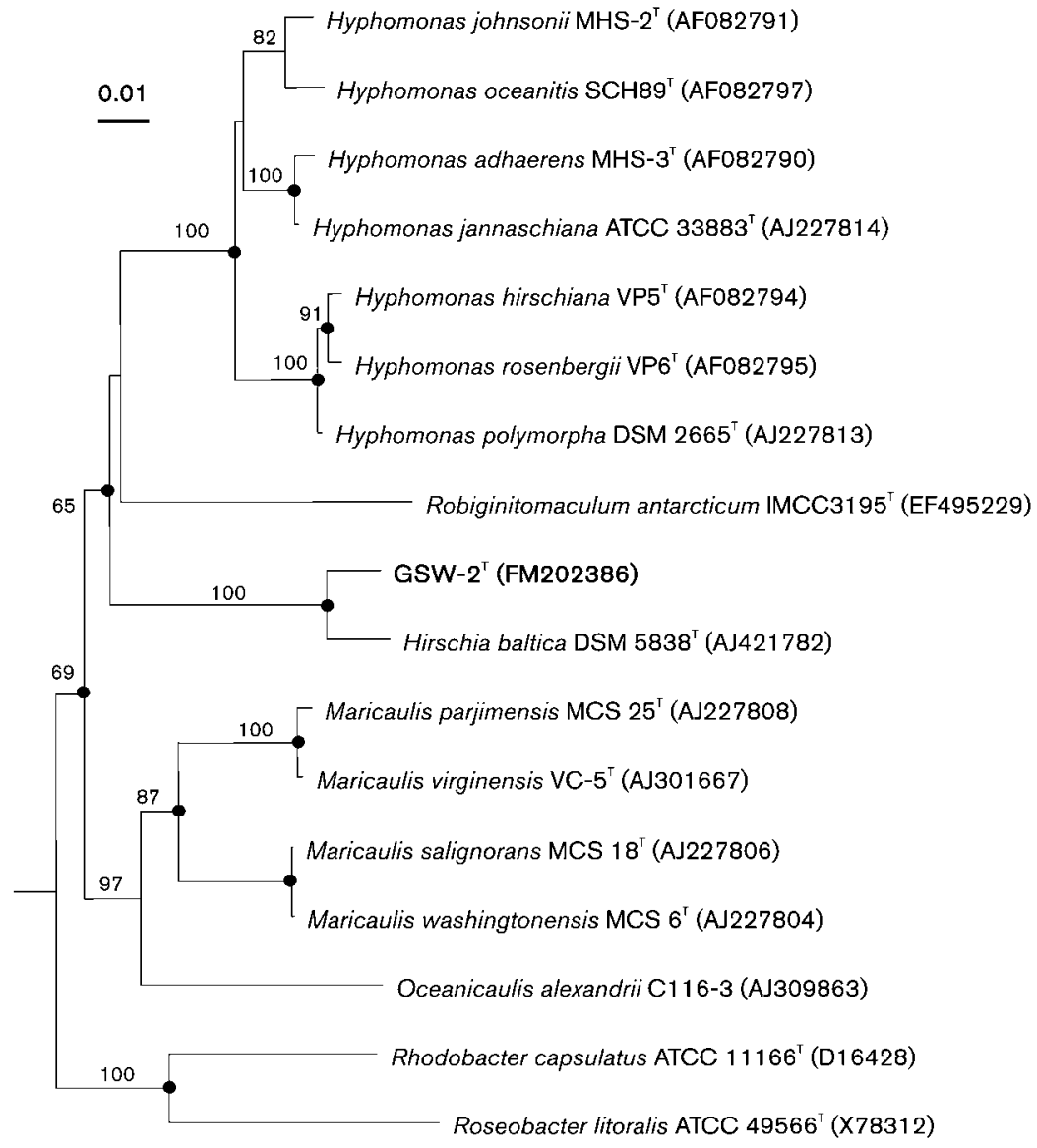

Fig. 2. Neighbour-joining tree based on $16 \mathrm{~S}$ rRNA gene sequences showing the phylogenetic position of strain GSW $-2^{\top}$ within the family Hyphomonadaceae. Closed circles indicate branches also found in both the maximumlikelihood (Felsenstein, 1981) and maximumparsimony (Fitch, 1971) trees. Bootstrap support values $(>50 \%)$ are shown at nodes. Bar, 0.01 substitutions per nucleotide position. gene sequence similarity of $97.5 \%$ ) within the family Hyphomonadaceae. This relationship was supported by a bootstrap value of $100 \%$ and was also recovered in trees obtained with both the maximum-likelihood (Felsenstein, 1981) and the maximum-parsimony (Fitch, 1971) algorithms. Strain GSW $-2^{\mathrm{T}}$ showed $16 \mathrm{~S}$ rRNA gene sequence similarity values of less than $91.4 \%$ with other representatives of the family Hyphomonadaceae.

For DNA-DNA hybridization experiments, genomic DNA was isolated by using a French pressure cell (Thermo Spectronic) and was refined by chromatography on hydroxyapatite as described by Cashion et al. (1977). DNA-DNA hybridization was carried out by using the spectrophotometric method (De Ley et al., 1970; Huß et al., 1983). The level of DNA-DNA relatedness between strain GSW $-2^{\mathrm{T}}$ and Hirschia baltica DSM $5838^{\mathrm{T}}$ was $13.6 \%$ ( $8.8 \%$ in duplicate measurements). This supports the conclusion that strain GSW $-2^{\mathrm{T}}$ can be assigned to a species distinct from Hirschia baltica (Wayne et al., 1987). Differential characteristics between strain GSW $-2^{\mathrm{T}}$ and Hirschia baltica DSM $5838^{\mathrm{T}}$ are given in Table 1 .

Based on phenotypic differences and DNA-DNA hybridization data, strain GSW $-2^{\mathrm{T}}$ is considered to represent a novel species of the genus Hirschia, for which the name Hirschia maritima sp. nov. is proposed.

\section{Description of Hirschia maritima sp. nov.}

Hirschia maritima (ma.ri'ti. ma. L. fem. adj. maritima of the marine environment).

Cells are aerobic, Gram-negative, oxidase-positive and catalase-positive. Vegetative cells produce a prostheca $(0.06-0.1 \mu \mathrm{m}$ in diameter) and reproduce by budding. Mature cells are spherical, oval- or rod-shaped and measure about $0.6-1.1 \times 1.2-1.3 \mu \mathrm{m}$. At maturity, both the vegetative cell and the bud produce one or more flagella. Colonies are circular, convex, entire, orange and measure $0.5-0.8 \mathrm{~mm}$ in diameter after 5 days incubation. Growth does not occur on any medium supplemented with natural seawater or artificial sea salts except for MA. Grows at $10-30{ }^{\circ} \mathrm{C}$ (optimum, $30{ }^{\circ} \mathrm{C}$ ), at $\mathrm{pH}$ 6.1-10.1 (optimum, $\mathrm{pH}$ 8.1-9.1) and on MA supplemented with $1 \%(\mathrm{w} / \mathrm{v})$ $\mathrm{NaCl}$. Produces a non-diffusible carotenoid pigment $\left[\lambda_{\max }=460 \mathrm{~nm}\right.$ in methanol/acetone $\left.(1: 1, \mathrm{v} / \mathrm{v})\right]$, but bacteriochlorophyll $a$ is absent. Degrades DNA and starch but not casein, chitin, CM-cellulose, elastin, gelatin, hypoxanthine, DL-tyrosine or xanthine. Positive for aesculin degradation and $\beta$-galactosidase, but negative for nitrate reduction, indole production, glucose fermentation, arginine dihydrolase and urease (API 20NE). Enzyme activities for alkaline phosphatase, leucine arylamidase, trypsin, acid phosphatase and naphthol-AS-BI-phospho- 
hydrolase are positive, but esterase (C4), esterase lipase (C8), lipase (C14), valine arylamidase, cystine arylamidase, $\alpha$ chymotrypsin, $\alpha$-galactosidase, $\alpha$-glucosidase, $\beta$-glucosidase, $\beta$-glucuronidase, $N$-acetyl- $\beta$-glucosamidase, $\alpha$-mannosidase and $\alpha$-fucosidase are negative (API ZYM). In the Biolog GN2 system, L-arabinose, D-fructose, myo-inositol, D-mannitol, Dmannose, D-psicose, D-sorbitol, sucrose, trehalose, methyl pyruvate, methyl succinate, acetic acid, D-gluconic acid, $\alpha$ hydroxybutyric acid, $\beta$-hydroxybutyric acid, $\alpha$-ketobutyric acid, $\alpha$-ketoglutaric acid, propionic acid, quinic acid, Dsaccharic acid, L-alanyl glycine, L-glutamic acid, L-serine, 2aminoethanol, glycerol, Tween 40, Tween 80, L-alanine, Lproline, $\alpha$-D-glucose, D-mannitol (weak), $\gamma$-hydroxybutyric acid (weak), phenylethylamine (weak), putrescine (weak) and 2,3-butanediol (weak) are oxidized. The following carbon substrates are not oxidized: $\alpha$-cyclodextrin, $N$-acetyl-Dgalactosamine, $\mathrm{N}$-acetyl-D-glucosamine, L-arabinose, myoinositol, formic acid, D-galactonic acid lactone, D-galacturonic acid, D-gluconic acid, malonic acid, citric acid, sebacic acid, succinic acid, bromosuccinic acid, D-alanine, L-alaninamide, L-asparagine, L-aspartic acid, glycyl L-glutamic acid, L-leucine, L-phenylalanine, D-serine, L-serine, $\gamma$-aminobutyric acid, 2 aminoethanol, glycerol, DL- $\alpha$-glycerol phosphate and Dglucose $\alpha$-6-phosphate. meso-Diaminopimelic acid is the diagnostic diamino acid of the cell-wall peptidoglycan. The predominant quinone is Q-10. The only polar lipid detected is phosphatidylglycerol. The major cellular fatty acids are components included in summed feature 7 and $\mathrm{C}_{16: 0}$.

The type strain, GSW $-2^{\mathrm{T}}\left(=\mathrm{DSM} 19733^{\mathrm{T}}=\mathrm{JCM} 14974^{\mathrm{T}}\right)$, was isolated from seawater taken from the seashore of Jeju, Republic of Korea. The DNA G + C content of the type strain is $44.5 \mathrm{~mol} \%$.

\section{Acknowledgements}

This work was supported by the 21C Frontier Microbial Genomics and Application Center Program, Ministry of Science \& Technology, Republic of Korea. We thank Dr R. Pukall for providing the type strain of Hirschia baltica.

\section{References}

Abraham, W. R., Strömpl, C., Meyer, H., Lindholst, S., Moore, E. R., Christ, R., Vancanneyt, M., Tindall, B. J., Bennasar, A. \& other authors (1999). Phylogeny and polyphasic taxonomy of Caulobacter species. Proposal of Maricaulis gen. nov. with Maricaulis maris (Poindexter) comb. nov. as the type species, and emended description of the genera Brevundimonas and Caulobacter. Int J Syst Bacteriol 49, 1053-1073.

Cashion, P., Holder-Franklin, M. A., McCully, J. \& Franklin, M. (1977). A rapid method of base ratio determination of bacterial DNA. Anal Biochem 81, 461-466.

De Ley, J., Cattoir, H. \& Reynaerts, A. (1970). The quantitative measurement of DNA hybridisation from renaturation rates. Eur $J$ Biochem 12, 133-142.

Felsenstein, J. (1981). Evolutionary trees from DNA sequences: a maximum likelihood approach. J Mol Evol 17, 368-376.

Felsenstein, J. (1985). Confidence limits on phylogenies: an approach using the bootstrap. Evolution 39, 783-791.
Felsenstein, J. (1993). PHYLIP (phylogeny inference package), version 3.5c. Distributed by the author. Department of Genome Sciences, University of Washington, Seattle, USA.

Fitch, W. M. (1971). Toward defining the course of evolution: minimum change for a specific tree topology. Syst Zool 20, 406-416.

Huß, V. A. R., Festl, H. \& Schleifer, K. H. (1983). Studies on the spectrophotometric determination of DNA hybridization from renaturation rates. Syst Appl Microbiol 4, 184-192.

Jukes, T. H. \& Cantor, C. R. (1969). Evolution of protein molecules. In Mammalian Protein Metabolism, pp. 21-132. Edited by H. N. Munro. New York: Academic Press.

Kroppenstedt, R. M. (1985). Fatty acid and menaquinone analysis of actinomycetes and related organisms. In Chemical Methods in Bacterial Systematics, pp. 173-199. Edited by M. Goodfellow \& D. E. Minnikin. London: Academic Press.

Lee, S. D. (2007). Tamlana crocina gen. nov., sp. nov., a marine bacterium of the family Flavobacteriaceae isolated from beach sediment in Korea. Int J Syst Evol Microbiol 57, 764-769.

Lee, K., Lee, H. K., Choi, T. H. \& Cho, J. C. (2007). Robiginitomaculum antarcticum gen. nov., sp. nov., a member of the family Hyphomonadaceae, from Antarctic seawater. Int J Syst Evol Microbiol 57, 2595-2599.

Mesbah, M., Premachandran, U. \& Whitman, W. B. (1989). Precise measurement of the $\mathrm{G}+\mathrm{C}$ content of deoxyribonucleic acid by highperformance liquid chromatography. Int J Syst Bacteriol 39, 159-167.

Minnikin, D. E., Patel, P. V., Alshamaony, L. \& Goodfellow, M. (1977). Polar lipid composition in the classification of Nocardia and related bacteria. Int J Syst Bacteriol 27, 104-117.

Minnikin, D. E., O’Donnell, A. G., Goodfellow, M., Alderson, G., Athalye, M., Schaal, A. \& Parlett, J. H. (1984). An integrated procedure for the extraction of bacterial isoprenoid quinones and polar lipids. J Microbiol Methods 2, 233-241.

Moore, R. L., Weiner, R. M. \& Gebers, R. (1984). Genus Hyphomonas Pongratz 1957 nom. rev. emend., Hyphomonas polymorpha Pongratz 1957 nom. rev. emend., and Hyphomonas neptunium (Liefson 1964) comb. nov. emend. (Hyphomicrobium neptunium). Int J Syst Bacteriol 34, 71-73.

Pongratz, E. (1957). D’une bactérie pédiculée isolée d'un pus de sinus. Schweiz Z Pathol Bakteriol 20, 593-608.

Saitou, N. \& Nei, M. (1987). The neighbor-joining method: a new method for reconstructing phylogenetic trees. Mol Biol Evol 4, 406-425.

Schlesner, H., Bartels, C., Sittig, M., Dorsch, M. \& Stackebrandt, E. (1990). Taxonomic and phylogenetic studies on a new taxon of budding, hyphal Proteobacteria, Hirschia baltica gen. nov., sp. nov. Int J Syst Bacteriol 40, 443-451.

Strömpl, C., Hold, G. N., Lunsdorf, H., Graham, J., Gallacher, S., Abraham, W.-R., Moore, E. R. B. \& Timmis, K. N. (2003). Oceanicaulis alexandrii gen. nov., sp. nov., a novel stalked bacterium isolated from a culture of the dinoflagellate Alexandrium tamarense (Lebour) Balech. Int J Syst Evol Microbiol 53, 1901-1906.

Thompson, J. D., Gibson, T. J., Plewniak, F., Jeanmougin, F. \& Higgins, D. G. (1997). The CLUSTAL_X windows interface: flexible strategies for multiple sequence alignment aided by quality analysis tools. Nucleic Acids Res 25, 4876-4882.

Wayne, L. G., Brenner, D. J., Colwell, R. R., Grimont, P. A. D., Kandler, O., Krichevsky, M. I., Moore, L. H., Moore, W. E. C., Murray, R. G. E. \& other authors (1987). International Committee on Systematic Bacteriology. Report of the ad hoc committee on reconciliation of approaches to bacterial systematics. Int J Syst Bacteriol 37, 463-464.

Weiner, R. M., Melick, M., O’Neill, K. \& Quintero, E. (2000). Hyphomonas adhaerens sp. nov., Hyphomonas johnsonii sp. nov. and Hyphomonas rosenbergii sp. nov., marine budding and prosthecate bacteria. Int J Syst Evol Microbiol 50, 459-469. 